\section{TOKOH PERJANJIAN LAMA DALAM PERJANJIAN BARU}

\author{
Dr. Byung Soo-Cho \\ Diterjemahkan oleh Daniel Keum
}

Kalau kita mengamati Perjanjian Lama (PL), kita dapat melihat tokoh-tokoh PL di mana beberapa tokoh dari PL tersebut sering muncul di dalam Perjanjian Baru (PB). Tokoh-tokoh dari PL itu kadang-kadang dipakai secara simbol, juga ditafsirkan secara teologis.

Dengan memperhatikan hal tersebut, nampak bahwa tokoh-tokoh dari PL bergerak kembali secara gamblang dalam PB. Jadi, antara PL dan PB bukanlah suatu catatan dan berita yang terpisah. PL memberikan badan dari mereka, PB memberikan nafas bagi mereka.

Beberapa tokoh PL yang terlihat dalam PB.

\section{Adam}

Nama Adam tidak sering disebut dalam PB. Ada beberapa ayat yang memuat nama Adam secara langsung dalam PB, yaitu: Lukas 3:38; Roma 5:14 (2 kali); 1 Korintus 15:22,45 (2 kali); 1 Timotius 2:13-14; Yohanes 14. Tentu Adam ditunjukkan secara tidak langsung dalam PB. Sebagai contoh, Yesus dicobai oleh iblis. Secara simbol hal ini berdasarkan pada iblis mencobai Adam dan Hawa (Matius 4:1-11; Markus 1:12-13; Lukas 4:1-13).

Ketika Yesus menentang demi perceraian dalam Matius 19:4-6, Firman-Nya berdasarkan pada fakta bahwa Allah menciptakan Adam dan Hawa. Kisah Para Rasul 17:26 mengatakan bahwa Allah yang memberikan hidup dan bahwa Ia juga menjadikan semua bangsa dan umat manusia dari satu orang saja. Ini mengingatkan pada Kejadian 2:7.

Ajaran Alkitab mengenai pemulihan gambaran Allah pada diri manusia berhubungan dengan fakta yang mana bahwa Adam diciptakan menurut gambaran Allah (Roma 1:23; 8:29; 2 Korintus 3:8; 4:4; Filipi 2:6-9; 3:12).

Ketamakan adalah dosa dasar yang membentuk pelanggaran manusia mengingatkan akan kejatuhan Adam dan Hawa (Roma 7:7-12).

Kalau begitu, mari kita selidiki ekspresi tentang Adam secara langsung dalam PB.

Pendapat Lukas

Dalam Lukas 3:8, Adam diperkenalkan sebagai bapa Yesus Kristus. Ini adalah untuk menjelaskan asal-usul Yesus. Tentu saja, Yesus tidak bermula secara langsung dari Adam, ada banyak orang di antara Adam dan Yesus. Yang penting adalah Adam berasal dari Allah. Adam adalah bukan keberadaan mandiri dan mutlak. Adam adalah keberadan subordinasi. Adam tidak ada nilai tanpa Allah.

Pendapat Paulus

Pernyataan yang paling penting tentang Adam bisa ditemukan dari Paulus. Rasul Paulus memahami Adam dari pandangan Kristologi dan Eskatologi.

\section{Pandangan Kristologi Paulus dalam Hubungannya dengan Adam}

Pertama, mari kita membahahas tentang Adam dengan memandang Kristologi Paulus. Rasul Paulus menggambarkan hubungan Yesus dan Adam dengan tipologi. Tipologi dari Yesus dan Adam yang Paulus pakai dimulainya dari dua arah.

Roma 5:12-21. Dari ayat ini terlihat bahwa Adam mewakili semua orang dalam pelanggaran manusia. Adam adalah tokoh yang mewakili semua bangsa, juga dia adalah wakil dari semua orang tentang dosa. Juga, Adam adalah gambaran Yesus yang akan datang (Roma 5:14-21). Adam dijelaskan sebagai tokoh pelanggaran karena ketidaktaatannya, 
sedangkan Yesus dijelaskan sebagai tokoh pemulihan karena ketaatan-Nya. Ketidaksetiaan Adam membawa maut, karena itu semua orang telah berbuat dosa dan menghadapi kematian. Tetapi ketaatan Yesus membawa Hidup, karena itu semua orang bisa mencapai hidup. Perbandingan Adam dan Yesus menunjukkan karunia Allah dan penaklukan kebenaran terhadap pelanggaran dan kejahatan manusia.

Dalam I Korintus 15, kita bisa menemukan beberapa pemakaian tipologi. Dalam 1 Korintus 15:21-22, Rasul Paulus mendefinisikan Adam sebagai pendiri yang membawa semua orang kepada maut. Sedangkan Rasul Paulus menyatakan bahwa Yesus Kristus adalah yang sulung dari orang-orang yang telah meninggal (I Korintus 15:20).

Menurut 1 Kor 15:45-49, diskripsi Paulus lebih maju. Adam yang diciptakan dengan keberadaannya adalah bentuk asli dari keberadaan manusia. Ini didasarkan pada Kejadian 1:26-27 dan 5:1-3. Sedangkan, Yesus Kristus adalah bentuk asli sebagai Adam yang kedua atau sebagai Adam yang terakhir secara eskatologis. Manusia pertama, Adam mewakili keadaan manusia yang belum menerima tubuh kebangkitan. Manusia kedua, yaitu Yesus mewakili keadaan manusia yang telah menerima tubuh kebangkitan.

Yang menentukan bahwa apakah seseorang telah menemukan tubuh kebangkitan atau tidak tergantung pada apakah orang tersebut sudah menerima kebangkitan dalam diri Yesus atau tidak. "Sama seperti kita telah memakai rupa dari alamiah, demikian pula kita akan memakai rupa dari yang surgawi" (1 Kor 15:49).

Menarik, bahwa istilah yang fungsinya berbeda dipakai menjelaskan Adam dan Yesus. Kalau Adam menjadi makhluk yang hidup, Yesus menjadi roh yang menghidupkan (I Kor. 15:45). Rasul
Paulus berpikir bahwa Adam adalah hidup, Yesus adalah roh dalam sisi keberadaan. Adam berasal dari debu dan tanah yang bersifat alamiah, Yesus berasal dari surga. Dalam pandangan Rasul Paulus, Adam adalah hanya makhluk yang hidup, sedangkan Yesus adalah yang menghidupkan.

\section{Pandangan Eskatologi Paulus dalam Hubungannya dengan Adam}

Yang kedua, mari kita lihat sisi eklesiologi dari Rasul Paulus tentang Adam. 1 Tim. 2:13-14, Rasul Paulus menyatakan bahwa perempuan harus berdiam di depan laki-laki. Ini adalah sesuatu tata tertib diantara laki-laki dan perempuan dalam gereja didasarkan pada sejarah asli dari Kejadian yang Adam yang Adam mempunyai hak khusus daripada Hawa. Paulus menekankan bahwa tata tertib diantara lai-laki dan perempuan berdasarkan Adam lebih dahulu diciptakan daripada Hawa.

Soal tentang tata tertib diantara lakilaki dan perempuan didasarkan pada tata tertib ciptaan Adam dan Hawa. 1 Kor. 11:7-9 menjelaskan ini secara sugestif. Juga Rasul Paulus memikirkan bahwa tata tertib laki-laki dan perempuan harus dijelaskan bahwa Hawa jatuh ke dalam dosa dahulu daripada Adam. Yang digodai oleh Iblis adalah Hawa bukan Adam. Ini menunjukkan bahwa perempuan digodai dengan mudah, sehingga perempuan harus menyerahkan dirinya kepada laki-laki. Dengan demikian Rasul Paulus menyimpulkan terhadap tata tertib di antar laki-laki dan perempuan dalam gereja.

Pendapat Yudas

Nama Adam disebut lagi dalam surat Yudas. Tetapi kali itu sebutan tentang nama Adam bukan untuk menyebutkan nama Adam, melainkan untuk menjelaskan Henokh. Surat Yudas menjelaskan bahwa Henokh adalah keturunan ketujuh 
dari Adam. Di sini ada beberapa arti bersambung dengan Adam. Kita memikirkan bahwa pembaca surat Yudas perlu mendengar Henokh adalah keturunan Adam.

Surat Yudas menerangkan bahwa Adam adalah manusia yang pertama karena Henokh termasuk ketujuh dari Adam dalam silsilah. Juga surat Yudas berbicara tentang kesalehan Henokh sambil menunjukkan bahwa Henokh adalah keturunan Adam, sehingga Adam adalah yang saleh.

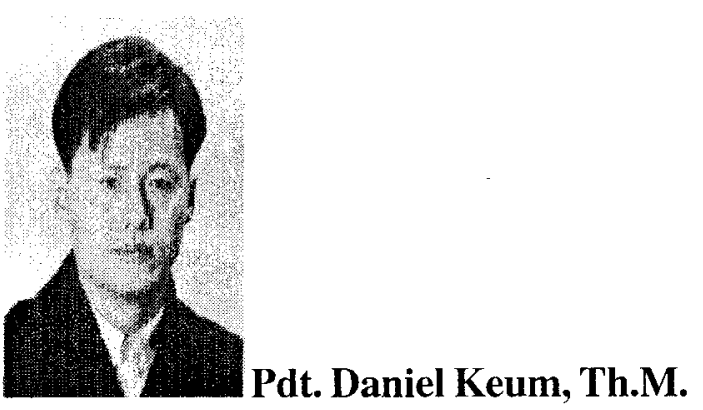

Dosen STT Jaffray utusan misi OMF dari Korea

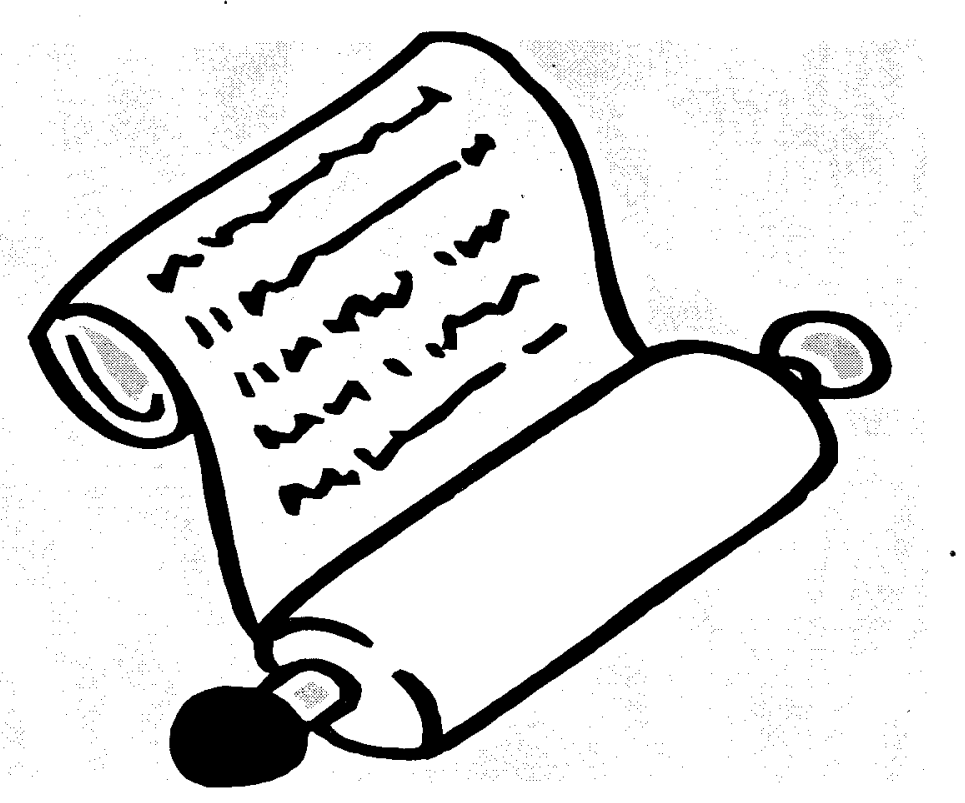

